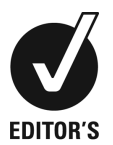

CHOICE

\title{
Pedunculated haemangioma of the palate
}

\author{
Abdulla Mufeed, ${ }^{1}$ Abdul Hafiz, ${ }^{2}$ Antony George, ${ }^{3}$ PG Francis ${ }^{4}$
}

${ }^{1}$ Department of Oral Medicine \& Radiology, MES Dental College, Perinthalmanna, Kerala, India

${ }^{2}$ Department of Paediatric Dentistry, MES Dental College, Perinthalmanna, Kerala, India Department of Oral Pathology, MES Dental College, Perinthalmanna, Kerala, India ${ }^{4}$ Department of Orthodontics, MES Dental College, Perinthalmanna, Kerala, India

\section{Correspondence to} Professor Abdul Hafiz, hafizzzdr@gmail.com

Accepted 21 January 2015

\section{SUMMARY}

Haemangiomas are the most common tumours of vascular origin of the head and neck region and can appear anywhere in the oral cavity. They are benign, appear in early childhood and usually involute as the child grows older. The dental surgeon should manage them appropriately if they are symptomatic. This report presents a rare case of a pedunculated haemangioma in a 4-year-old child.

\section{BACKGROUND}

Intra-oral soft tissue swellings are often overlooked and provisionally considered as inflammatory lesions. Clinicians should be familiar with such unusual presentations so that they are treated appropriately.

\section{CASE PRESENTATION}

A 4-year-old girl reported to the Department of Paediatric Dentistry with a swelling on the palate. According to her parents, an initially small lesion had gradually increased in size and was painless but impaired her speech.

Systemic examination revealed that the child was normally built for her age and there was no medical, dental or family history of relevance. On intra-oral examination, a single swelling was seen on the palatal midline. It was pedunculated, reddish pink in colour, lobulated, soft and measured about $3 \times 3 \times 2 \mathrm{~cm}$ in diameter (figure 1). Mild blanching was noticed on applying pressure.

\section{INVESTIGATIONS}

A routine haematological examination performed according to the institutional protocol for undergoing minor surgical procedures was normal.

\section{DIFFERENTIAL DIAGNOSIS}

In view of the colour, consistency, lobulated surface and pedunculated appearance of the swelling, a differential diagnosis of pyogenic granuloma, haemangioma and squamous papilloma was made.

\section{TREATMENT}

The lesion was excised under local anaesthesia. There was more profuse bleeding from the site than expected which was stopped using electrocautery. A periodontal pack (zinc oxide eugenol paste) was placed to prevent clot dislodgement.

\section{OUTCOME AND FOLLOW-UP}

The excised specimen underwent histopathological evaluation. The microscopic picture showed stratified squamous epithelium with associated fibrovascular connective tissue. The stroma had multiple small- and large-diameter well-developed vascular

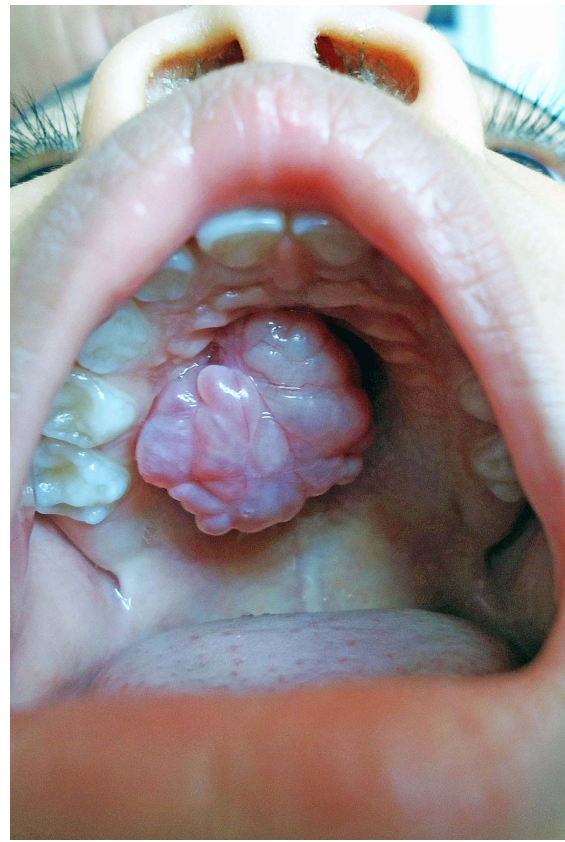

Figure 1 The lobulated swelling on the palate.

channels lined with endothelial cells, some of which were congested with red blood cells (figure 2). No inflammatory component was seen. Histopathology was suggestive of infantile haemangioma.

The post-surgery period was uneventful. At 1-week follow-up, the parents reported that the child's speech was improving.

The patient presented again after 8 months with another similar lesion, but smaller in dimension $(1 \times 1 \mathrm{~cm})$ and on the antero-lateral aspect of the palate (figure 3). No action was taken as it was asymptomatic, but it was placed under observation.

\section{DISCUSSION}

Haemangiomas are relatively common benign proliferations of vascular channels that may be present at birth or arise during early childhood. ${ }^{1}$ Currently, haemangiomas are considered to be benign tumours of infancy that are characterised by a rapid growth phase with endothelial proliferation, followed by gradual involution. Most haemangiomas are not present at birth but subsequently develop during the first 8 weeks of life. ${ }^{2}$

The majority of haemangiomas involve the head and neck. They are rare in the oral cavity but may occur on the tongue, lips, buccal mucosa, gingiva and palatal mucosa. ${ }^{3-6}$

Clinically, haemangiomas appear as a smooth or lobulated soft mass, are sessile or pedunculated, and may vary in size from a few millimetres to several centimetres. They are usually deep red and 


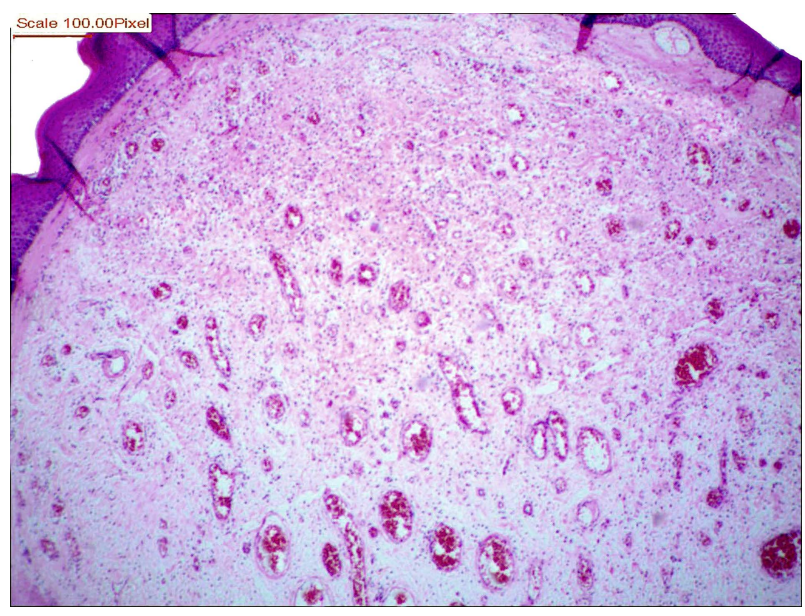

Figure 2 Histopathology (×10 magnification) showing vascular channels lined with endothelial cells.

may blanch on the application of pressure and, if large, can interfere with eating. ${ }^{3}$ Pedunculated haemangiomas of the oral cavity are extremely rare. ${ }^{7}$

Haemangiomas are benign tumours of the blood vessels and are classified according to their histopathological appearance as capillary, mixed cavernous, or sclerosing, a variety that tends to undergo fibrosis. ${ }^{8}$ Haemangiomas grow by endothelial hyperplasia and should be differentiated from vascular malformations, which are not true neoplasms but are localised defects of vascular morphogenesis caused by dysfunction in embryogenesis and vasculogenesis. ${ }^{4}$ Haemangiomas are the most common benign soft tissue tumour of infancy and childhood, occurring in 12\% of all infants, and are found in greater frequency in girls, white children, premature infants, twins, and those born to mothers of higher maternal age. ${ }^{8}$ The incidence in the Indian population has not been reported. ${ }^{9}$ Haemangiomas occur frequently in the head and neck region (60\%), followed by the trunk (25\%) and the extremities (15\%), and are grouped into infantile haemangi-

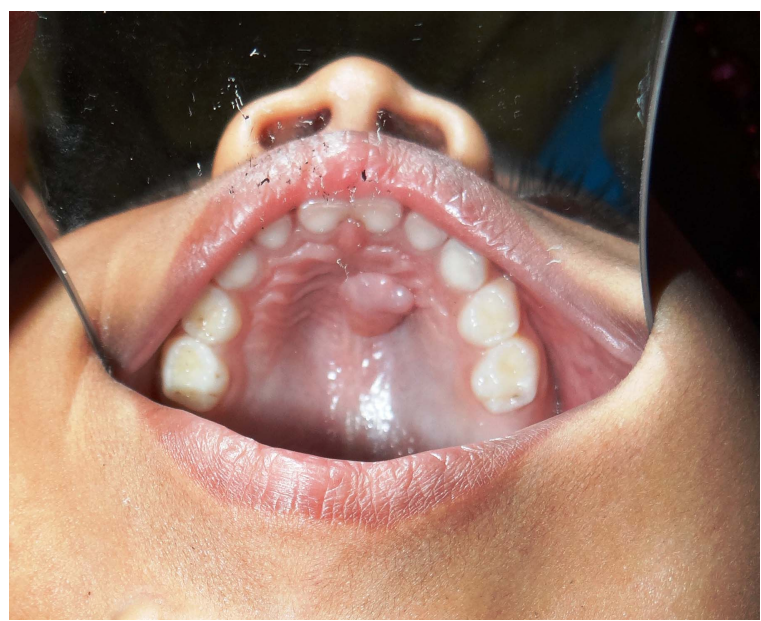

Figure 3 Recurrence of a similar swelling at an anterior site. oma and congenital haemangioma. They rarely occur on the palatal mucosa. ${ }^{10}$

The pathogenesis and origin are not clearly understood. A variety of other lesions resemble haemangioma such as pyogenic granuloma, chronic inflammatory hyperplasia, epulis granulomatosa, telangiectasia and angiosarcoma. ${ }^{9}$

The management of haemangioma depends on a number of factors and most true haemangiomas require no intervention. However, 10-20\% of cases require treatment because of their size, location, stage of growth, behaviour and functional compromise. ${ }^{6}$ The range of treatment includes surgery, flashlamppulsed laser, intra-lesional injection of fibrosing agent, treatment with interferon $\alpha$, electrocoagulation and radiation. ${ }^{11} 12$

In our patient, since the tumour was causing difficulty in swallowing and was impairing speech, surgical excision was carried out.

\section{Learning points}

- Intra-oral haemangiomas can have a varying clinical appearance and may mimic inflammatory lesions such as pyogenic granuloma.

- Intra-operative complications such as bleeding should be anticipated and precautions taken during excision of even smaller benign-appearing lesions.

- A decision to observe the lesion may be taken if the diagnosis is haemangioma and it does not interfere with function or aesthetics, as $90 \%$ of them involute by 9 years of age.

Competing interests None.

Patient consent Obtained.

Provenance and peer review Not commissioned; externally peer reviewed.

\section{REFERENCES}

1 Sapp JP, Eversole LR, Wysocki W. Contemporary oral and maxillofacial pathology. 2nd edn. Mosby, 2004:319-22.

2 Neville B, Damm DD, Allen C, et al. Oral and maxillofacial pathology. WB Saunders, 2004:467-71

3 Maaita JK. Oral tumors in children: a review. J Clin Pediatr Dent 2000;24:133-5.

4 Hall RK. Paediatric oro-facial medicine and pathology. Chapman \& Hall, 1994.

5 Dilsiz A, Aydin T, Gursan N. Capillary haemangioma as a rare benign tumor of the oral cavity: a case report. Case J 2009;9:8622.

6 Gill JS, Gill S, Bharadwaj A, et al. Oral haemangioma. Case Rep Med 2012;2012:347939.

7 Kitano H, Sekiya W, Yamada T, et al. Pedunculated haemangioma of the hard palate. Asian J Oral Maxillofac Surg 2009;21:120-2.

8 Acikoz A, Sakkaliagolu U, Ozdamar S, et al. Rare benign tumors of the oral cavitycapillary hemangioma of the palatal mucosa: a case report. Intl J Paed Dent 2000;10:161-5.

9 Rachappa MM, Triveni MN. Capillary hemangioma or pyogenic granuloma: a diagnostic dilemma. J Contemp Clin Dent 2010;1:119-22.

10 Barak S, Katz J, Kalan I. The CO2 laser in surgery of vascular tumor of the oral cavity in children. J Dent Child 1991;58:293-6.

11 Greene LA, Freedman PD, Friedmolf M. Capillary haemangioma of the maxilla: a report of two cases in which angiography and embolization were used. Oral Surg Oral Med Oral Pathol 1990;70:268-73.

12 Buckmiller LM, Richter GT, Suen JY. Diagnosis and management of haemangioma and vacular malformations of the neck. Oral Dis 2010;16:405-18. 
Copyright 2015 BMJ Publishing Group. All rights reserved. For permission to reuse any of this content visit http://group.bmj.com/group/rights-licensing/permissions.

BMJ Case Report Fellows may re-use this article for personal use and teaching without any further permission.

Become a Fellow of BMJ Case Reports today and you can:

- Submit as many cases as you like

- Enjoy fast sympathetic peer review and rapid publication of accepted articles

- Access all the published articles

- Re-use any of the published material for personal use and teaching without further permission

For information on Institutional Fellowships contact consortiasales@bmjgroup.com

Visit casereports.bmj.com for more articles like this and to become a Fellow 